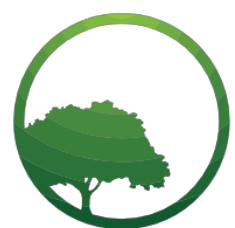

Business \& Social Science IJRBS

\section{Research in Business and Social Science}

IJRBS Vol 8 No 1, ISSN: 2147- 4478

Contents available at www.ssbfnet.com/ojs

\title{
Influence of Talent Management Practices on Turnover Intent among Research Scientists at the National Museums of Kenya (NMK), Nairobi
}

\author{
Nicholas Ochieng' Ojwang'
}

Department of Business Administration, University of Nairobi, Nairobi, Kenya.

ORCID ID: 0000-0002-9411-7554

\begin{abstract}
Human talent represents a source of competitive advantage. Yet the very people organisations would want to retain are the ones most likely to leave. What determines employee turnover is a vital question to organisations facing business continuity challenges. Through the prism of the Human Capital and Social Exchange theories, this study aimed at examining the influence of Talent Management practices on turnover intent among Research Scientists at the National Museums of Kenya, Nairobi. Data was collected by means of a structured questionnaire formulated based on extensive literature review. The study targeted 128 employees designated as Research Scientists at the time of conducting this study. Results indicate very high levels of engagement among Research Scientists at NMK. Though respondents understand how their performance is evaluated, the link between pay and performance appears unclear to them. Ample learning and growth opportunities do exist but identification of training needs is not methodical. The study also revealed a clear dissatisfaction with the total compensation package. Although majority of respondents believed that advancement opportunities existed, they were less confident regarding existence of equal opportunity for such advancement. Regression analysis of results indicated that of the six independent variables studied, only employee engagement had significant relationship with employee turnover intent. The study concludes that employee engagement is a critical factor in keeping employees in the organisation. It is recommended that NMK develops effective retention strategies to ensure that Research Scientists remain engaged and committed. An integrated rewards scheme incorporating non-financial factors, career development and work-life balance should form part of the strategy. In addition, a formalised induction program as well as a systematic learning and development scheme with individualised plans needs to be put in place.
\end{abstract}

Key words: Talent Management, Turnover Intent, Employee Turnover, Retention, Engagement, Research Scientists. 


\section{Introduction}

The ever more critical need for organisations to get the right people, with the right skills, to do the right things, at the right time to attain business objectives calls for an ongoing process that identifies and plans for talent, attracts and finds new talent, develops talent and keeps the best in the company (Herholdt, 2012). Business performance can only be enhanced by improving the people that run an organisation. According to StewartBurton (2016), one of the cardinal sins that an organisation can commit is under-investment in people that work there. According to the 19th Annual Global CEO survey by PWC, $72 \%$ of CEOs said availability of key skills was a major worry (PWC, 2016). The turnover of key staff could have a more than proportionate impact on a company. Crucially, the very people that organisations would want to keep are the ones most likely to depart (Armstrong, 2007). Where demand of critical skills and leaders outstrips supply, organisations have to be more appealing to talented persons while building a culture of high performance, engagement and growth (Herholdt, 2012). An organisation that is more attractive to prospective and current employees will be able to attract and keep a higher level of skill and talent.

Talent Management is the deployment of an inter-linked combination of interventions to ensure an organisation attracts, develops, motivates and keeps the talent it requires at present as well as in the future (Armstrong, 2007). Heathfield (2016) describes Talent Management as the commitment by an organisation to recruit, retain, and develop the most talented and superior employees obtainable from the labour market. Herholdt (2012) defines it as the proactive management and balancing of the demand for critical skills against the stock of critical skills in both the near term as well as in the future so as to guarantee the functional continuity and sustainability of the business. The scope of Talent Management according to Oladapo (2014) falls into 5 key areas of recruitment, training and development, performance management, succession planning and retention; every one of which plays an important part in Talent Management. McCracken et al (2015) see TM as involving an array of practices and activities, from employer branding, recruitment and selection, training and development, succession planning, and retention management while Haider et al (2015) identify some of the important practices as compensation, training and development and organisation culture.

Organisations must link talent to overall company strategy. Businesses have to spell out what constitutes their core strategies, and proceed to recruit and retain individuals with the talent required to execute those strategies (Stewart-Burton, 2016). The ultimate aim of Talent Management is developing and maintaining of a reservoir of talent made up of a skilled, engaged and committed labour force (Armstrong, 2007). It is the set business strategy that will ensure attraction of the best talent in competition with rival employers. Turnover intent reveals the subjective likelihood that one will leave an organisation and is thus indicative of one's attitude towards the organisation (Santhanam et al, 2017). It does not necessarily equate to actual turnover. However, it is a powerful signal for actual quitting behaviour (Firth et al, 2004). The question as to what determines employee turnover is of great relevance to individuals thinking about quitting their jobs as well as to organisations facing business continuity challenges. Once people have quit, there is little likelihood of getting to them so as to understand their prior situation. High attrition rates cost businesses in time and productivity. An organisation faced with the abrupt resignation of its best employee has to find a substitute for such talent which is not easy where demand for skilled professionals is high. In industries with lengthy production cycles, training a new employee can take months (Johnson and Fahsholtz, 2010). Whenever an employee leaves others notice with some beginning to wonder if they should follow suit. Perhaps most critical is the disengagement displayed by many employees long before they leave. According to Branham (2005), disengaged employees lack commitment, are marginally productive, frequently absent, or worse, work actively against company interests. It follows from the above arguments that employee retention ought to be on every company's list of top priorities.

National Museums of Kenya (NMK), a government institution created by the Museums and Heritage Act 2006 is a multi-disciplinary institution charged with collecting, preserving, studying, documenting and showcasing Kenya's past and contemporary cultural and natural heritage so as to increase knowledge, appreciation, respect and sustainable utilisation of these resources for the benefit of Kenya and the world, for now and the future (National Museums of Kenya, 2017). Research is one of four key functions of the National Museums of Kenya. NMK conducts research based on cultural and natural history in various fields as well as research in biomedicine and bio- conservation in partnership with other research and development institutions. The Institute of Primate Research (IPR) is an institution of the NMK which conducts research on biomedical/animal welfare and conservation aspects using East African primates. It is located inside Ololua Forest near Karen in Nairobi. 
Human talent is one of the most important investments that firms make. Companies have recognised that talent represents a source of competitive advantage (Ashton and Morton 2005; Martin, 2015) and that competition goes beyond market share to what Bluen (2013) calls "talent share". Torrington et al (2008) state that most recruitment pressures are caused by turnover, not growth and warn that an organisation which fails to recruit and retain the talent it needs is destined to fail. Where employees are more specialised, more difficult to find and require more training, the costs of labour turnover will be higher (Graham \& Bennett, 1998). One key individual can hold the fortunes of a business in their hand (Rankin, 2003). In today's world, employees favour work environments where they develop, re-invent themselves, learn continuously and where their ideas are likely to be embraced and encouraged (Isfahani and Boustani, 2014). Deployment of more Talent Management practices by an organisation signals its interest in investing in its people thus enhancing the psychological connection between organisation and employees and resulting in lesser turnover intentions (Narayanan, 2016).

Previous studies on Talent Management in Kenya have addressed Talent Management practices from various standpoints and focused on various organisations and sectors. They have also underlined the relationship between Talent Management and employee turnover. However, these studies have neither focused specifically on National Museums of Kenya nor on research scientists. Clearly, a knowledge cap exists which this study seeks to bridge by providing answers to the question: What is the influence of Talent Management Practices on turnover intent among research scientists at National Museums of Kenya? To examine the influence of Talent Management practices upon turnover intent among Research Scientists at National Museums of Kenya, Nairobi.

This study will provide HR practitioners in Kenya's public research institutions with valuable insights on Talent Management and employee turnover and how to design appropriate strategies to attract, develop and keep the best people. In a Talent Management system, attracting and retaining talented employees is the work of each member of the organisation even though managers with staff reporting to them bear more responsibility (Heathfield, 2016). Accordingly, management and employees of NMK will benefit by having more clarity on their role in the Talent Management process. Insights from this study will be valuable to policy makers in state corporations, research institutions (public and private) as well as relevant government agencies. By implementing recommendations from the study, it is expected that they will improve employee retention and therefore reap the benefits of retaining top talent.

This study will augment the existing body of literature on influence of Talent Management practices on employee turnover intent. More specifically, researchers and scholars will use the findings and information from the study to reinforce their understanding of Talent Management and employee retention among research scientists and knowledge workers in general. Gaps that might be left by the researcher in the course of conducting this study will be used as a basis for further studies.

\section{Literature Review}

The Human Capital Theory and the Social Exchange Theory are the theoretical lenses through which this study views the link between Talent Management and retention.

Human Capital Theory was originally developed by Becker (1962). It is concerned with the value that people add to organisations. Baron and Armstrong (2007), state that human capital is a key constituent of organisation's intangible assets and that the knowledge, imagination and inventiveness of employees are as crucial to business success as are hard assets. The basic assumption of HCT is that training will lead to higher productivity for employees which will benefit the organisation and be passed on in the form of higher wages (O'Meara \& Petzall, 2013). The potential of human capital as against physical capital and organisational capital, to contribute significantly and in a lasting manner to sustainable competitive advantage is increasingly being recognised (Holland et al, 2007). Where non-human resources are accessible to all companies in an industry, quality human resources becomes a significant differentiating factor in firm performance (Holland et al, 2007). Human capital advantage relates to the recruitment and retention of outstanding people by securing a supply of exceptional talent, with productive potential (Robinson, 2006).

According to Emerson (1976), the Social Exchange Theory (SET) was originally advanced by Homans (1958), Thibaut \& Kelly (1959) and Blau (1964). Social exchange consists of actions conditioned upon the rewarding responses of others, which gradually give rise to reciprocal and beneficial transactions and relations (Cropanzano and Mitchell, 2005). Since individuals reciprocate benefits received, they are bound to match goodness and kindness to the person with whom they have a social exchange relationship. 
Employees actively engaged in their organisation may feel an obligation to respond and repay the organisation in some form, say by increasing their commitment to the organisation. Talent Management is a mutual investment relationship, where employees benefit from career development and organisations from enhanced performance.

\section{Recruitment and Selection}

According to Branham (2005), tomorrow's turnover arises from today's hiring mistakes. It is therefore critical that the hiring manager in coordination with the HR department clearly spell out talent requirements, recruit from the right sources, assess, screen and interview candidates effectively and hire people who will enable the organisation to successfully execute its business strategies. Concluding that the best form of recruitment is retention, Fields (2001) asserts that recruitment initiatives and retention are inextricably tied together and organisations should view them as such. Organisations should focus as much if not more on internal recruitment strategies as they do external recruitment initiatives (Fields, 2001; Branham, 2005). Apart from ensuring a ready stream of internal workers is available to occupy crucial positions (Fields, 2001), vacancies are opportunities to show employees that their organisation cares about them and will reward those who excel (Branham, 2005). It is important to ensure that prospective employers and their organisation share similar values as far as possible (Armstrong, 2006; Branham, 2005). These values may be stated during employment interviews or may be derived from company mission statements (Johnson and Fahsholtz, 2010). Bearing in mind the impact of unrealistic expectations on retention, experienced managers discuss the results and standards expected prior to an applicant accepting the position, not afterwards (Branham, 2005).

For recruitment to be deemed effective, all qualified or potentially qualified applicants should know about the organisation and positions or career opportunities being offered (Hayes and Ninemeier, 2001). Diversity in staff leads to a dynamic, creative workplace and raises an organisation's standing as Employer of Choice. A post hiring interview could be used to collect valuable information about the organisation and its recruiting strategies (Hayes and Ninemeier, 2001).

\section{Performance Management}

Performance management is the continuous process of identifying, measuring and developing individual and team performance and linking that performance with organisational goals (Dessler, 2013). Cascio (2014) likens it to a compass with the manager's job being to identify a person's current position and point effort and attention in the right direction. The importance of assessing, coaching, and rewarding performance in retaining talent cannot be overemphasised. Want of performance coaching and feedback ranks as a main cause of employee disaffection and turnover. So that employees' efforts remain linked to organisational and departmental objectives and expectations of supervisors, companies need to give feedback and coaching (Brahnam, 2005). This alignment is a vital prerequisite for employee engagement. Performance management includes financial rewards and incentives. Thanks to a dynamic labour force and changing work, areas of non-financial recognition and assessment and rewarding of team performance have increased in importance (Akridge, 2016)). In a survey of Australian organisations, Smith et al (2011) concluded that the use of appraisal results for training needs evaluation is a special long-term positive driver of employee turnover and skill retention. They also observed that frequent appraisals reduce turnover for workers with intermediate skills, while merely conducting appraisals reduces turnover of workers with basic skills.

Performance management has come a long way from yearly appraisal and rating to ongoing feedback and coaching, and from yearly goals and objectives to quarterly or more frequent objective setting, with informal check-in processes (Cascio, 2014). Development is now at the core of performance-management process rather than an after-thought. There is also an emphasis on giving top performers markedly higher amounts of compensation compared to middle or lower level performers. Performance review is central to Talent Management given that it provides input for reward system, staff development and succession plans. It aids in evaluation of workforce competencies and providing feedback to employees; feedback which is key in retention (Kibui, 2015).

\section{Learning and Development}

Human Capital Management is based on the conviction that people are assets and investing in them will create added value. Learning and development programmes are the major vehicles for such investments (Baron and Armstrong, 2007). The word development connotes an ongoing process with progress made over time; fitting in with current stress on learning for life. The organisation profits by retaining talent within, which in turn helps it to attain current and future strategic objectives (Foot and Hook, 2005).

Learning and Development helps draw individuals to an organisation and secure their commitment. Training helps create a desire amongst employees to remain in an organisation longer (Haider et al, 2015). Smith et 
al (2011) reiterate this point by stating that employees remain in organisations if they feel they are learning and advancing in their careers, and that organisations should offer opportunities for employee development. Any temptation to quit is reduced when employees feel that they are presented with the chance to learn and grow. Key individuals become more likely to stay with the organisation rather than leave for pastures green. A counter perspective is that with training, people become more employable and therefore likelier to depart and develop their careers elsewhere (Hlavna, 1992).

\section{Career Management}

Dessler (2013) defines career management as the process of making employees better understand and develop their career skills and interests and put these skills into the most effective use in the organisation and beyond. Career development plays a crucial part in engaging and retaining employees. Employees, with better understanding of their occupational strengths, are better equipped to serve the company. Perhaps more importantly, facilitating an employees' career development boosts their engagement and supports recruitment and retention efforts. Davis (2015) advocates for career development management beginning at recruitment with available career options and specific career development offerings being promoted in advertisements to attract top talent. This way, potential recruits avoid applying to organisations with inadequate career opportunities thus averting resentfulness and disengagement later. In most companies, career growth and advancement routinely feature among the top 3 reasons employees remain or leave (Branham, 2005). Top performers seek jobs and careers with employers who infuse additional effort into facilitating employees learning, growth, and internal advancement. Employers of choice not only clearly state that employees take charge of their own career development; they also provide the requisite tools and training.

\section{Employee Engagement}

Gallup, the advisory and research firm gauges employee engagement based on workers' responses to its Q12 survey; a set of 12 actionable workplace parameters with demonstrated links to performance. Based on their responses, Gallup classifies employees as engaged, not engaged, and actively disengaged. As Gallup puts it, besides being unhappy at work, disengaged employees undermine what their engaged colleagues accomplish. Noe (2010) states that one indicator of great firms is their capacity and readiness to discharge employees engaging in counterproductive acts and that one of the secrets of retaining productive workers is ensuring that they are not sabotaged by superiors or colleagues engaging in meaningless, disruptive, or dangerous behaviour. Engaged employees are passionate about their work and bear a profound attachment to the company. They lead innovation and steer the organisation forward. According to Morgan (2014), the essence of an engaged employee is a person who is interested in and enjoys the work that they do and feels connected to colleagues and the organisation they work for. According to Akridge (2016), creating a culture and climate where employees yearn to be, is a key role of firm leadership. Turnover, like many employee actions indicate the extent to which employees are engaged (Dessler, 2013). Employee engagement is critical - the personal commitment of employees and their willingness to go the extra mile is without replacement (Bluen, 2013). Employee engagement is the point past commitment; employees might feel committed to colleagues, customers, work or employer yet fail to go that extra mile or work beyond the contract (Foot and Hook, 2005).

\section{Compensation}

Usually employers that offer the most attractive compensation package exhibit lower turnover rates compared to those that pay poorly (Gomez-Mejia et al, 2010). This leads many firms to use pay as their number one weapon in staff retention. Haider et al (2015) assert that the remuneration that an organisation gives its employees indicates the commitment and intention towards them and is one among factors that compel an employee to stay. Citing Bevan et al (1997) and Hiltrop (1999), Torrington (2011) states that there is evidence suggesting that pay is considerably less important than other aspects in deciding to quit a job. Increasing pay may increase job satisfaction where people are already happy with their work, but will not stop disgruntled workers from departing. Pay as a staff retention strategy can easily be countered by rivals. Berger and Berger (2014) aptly articulate the role of compensation in retention by stating that it could be a powerful retention tool, but only within the context of a holistic combination of tangible and intangible rewards operating within the scheme of a reward philosophy that supports a winning business strategy.

\section{Talent Management and Employee Turnover}

Effective Talent Management guarantees that organisations can successfully procure and keep key talent (Hughes and Rog, 2008). Retention is vital to the proper operation and competitiveness of a firm and should therefore be high on the agenda of any organisation that desires to sustain its competitiveness. Scholars and 
researchers have conducted numerous studies that attempt to show the link between Talent Management and employee retention.

A study by Akhtar et al (2015) on total rewards and retention in universities in Pakistan indicated a strong and significant relationship. The data was gathered using self administered questionnaires from a sample of 350 faculty members from 10 public and private universities in Islamabad and Rawalpindi. Thite (2010) conducted a survey on factors influencing retention in the Indian ITES/BPO industry. The study, which combined employee survey and managerial interviews, covered 4 large Indian ITES/BPO firms and involved 638 customer service representatives (CSRs) and 15 Human Resource and operations managers. Employees mentioned satisfaction with wages (27\%), work satisfaction $(20 \%)$, and progression opportunities $(17 \%)$ as 3 main considerations that made them remain in their present employment. Others were: job security $(13 \%)$, want of alternative career options $(8 \%)$, flexible work-hours $(7 \%)$, fairness by management $(5 \%)$, and relationships at the workplace $(4 \%)$. Discontent with wages $(39 \%)$, want of progression opportunities $(22 \%)$ and routine/tedious jobs $(7 \%)$ were listed as the three major factors that moved employees to seek alternative career options.

A study by Kataike (2010) established a strong link between Talent Management and employee retention in Kenyan commercial banks. The variables under consideration included among others, feedback on career progress, job enrichment, and promotion. A survey by Yonga et al (2012) on Kenya's health care system significantly affected by brain drain - found that $85 \%$ of respondents had pondered, or were considering seeking employment outside of Kenya. 90\% reported not being happy with their pay. 288 doctors aged 50 and below from seven provinces participated in the study. The doctors were picked at random from public provincial, district, and private hospitals. Kibui (2015) conducted a study on the effect of Talent Management on employee retention in Kenya's state companies. Data was collected from heads of departments drawn from different categories of 162 state corporations in Kenya. A total 385 questionnaires were issued from which 382 were completed and returned; a response rate of $99.2 \%$. The results of the study established that the variables performance management, employee engagement and career development had a significant positive influence on employee retention.

\section{Research and Methodology}

The study focused on all employees at the National Museums of Kenya in Nairobi designated as Research Scientists at the time of conducting the study. As per figures provided by NMK's HR and Administration department, the number of Research scientists in Nairobi stood at 128. A breakdown of this figure per department is provided below (Table 1).

Table 1: Distribution of Research Scientists by department

\begin{tabular}{lll}
\hline Department & No. of Research Scientists & Percent \\
\hline Antiquities and monuments & 6 & 4.7 \\
Botany & 17 & 13.3 \\
Centre for Biodiversity & 11 & 8.6 \\
Cultural Heritage & 11 & 8.6 \\
Earth sciences & 14 & 10.9 \\
Institute of Primate Research & 35 & 27.3 \\
Zoology & 34 & 26.6 \\
Total & 128 & 100.0 \\
\hline
\end{tabular}

Source: HR \& Administration Department, NMK (2017)

A structured questionnaire formulated based on a broad review of literature was used for data collection. The questionnaire consisted of four sections. Section I sought information on the respondents' demographic profile while section II sought information on Talent Management Practices. Section III focused on employee turnover intent. Section IV afforded the respondent an opportunity to provide any other information they deemed appropriate for the study. This was optional. Statements in sections II and III were evaluated on a 5 point Likert scale ranging from "strongly agree" to "strongly disagree". Questionnaires were hand delivered to the respondents and collected at a pre-agreed time within the period of study. 
Data collected was then sorted, cleaned, coded and analysed using version 25 of the Statistical Package for the Social Sciences (SPSS) software. Descriptive statistics: frequency, percentage, mean and standard deviation have been used to establish trends so as to make it easier to understand and make inferences from the findings. Data is presented in the form of tables and graphs. The relationship between the dependent variable (turnover intent) and independent variables (Talent Management practices) was analysed using Multiple Regression. The regression model applied was:

$y=\beta_{0}+\beta_{1} x_{1}+\beta_{2} x_{2}+\beta_{3} x_{3}+\beta_{4} x_{4}+\beta_{5} x_{5}+\beta_{6} x_{6}$

Where,

$y$ is the value of the dependent variable (employee turnover intention)

$\beta_{0}$ is the constant

$\beta_{n}(n=1 . \ldots .6)$ is the coefficient of determinant

$\mathrm{x}_{1}$ is Recruitment and Selection

$\mathrm{x}_{2}$ is Performance Management

$\mathrm{x}_{3}$ is Learning and Development

$\mathrm{x}_{4}$ is Career Management

$\mathrm{x}_{5}$ is Employee Engagement

$\mathrm{x}_{6}$ is Compensation and Rewards

\section{Results and Discussion}

72 filled in questionnaires representing a response rate of $56.25 \%$ were received back from the respondents. A response rate of $50 \%$ is considered acceptable for analysis (Mugenda and Mugenda, 1999). Figure 1 shows the spread of respondents by department.
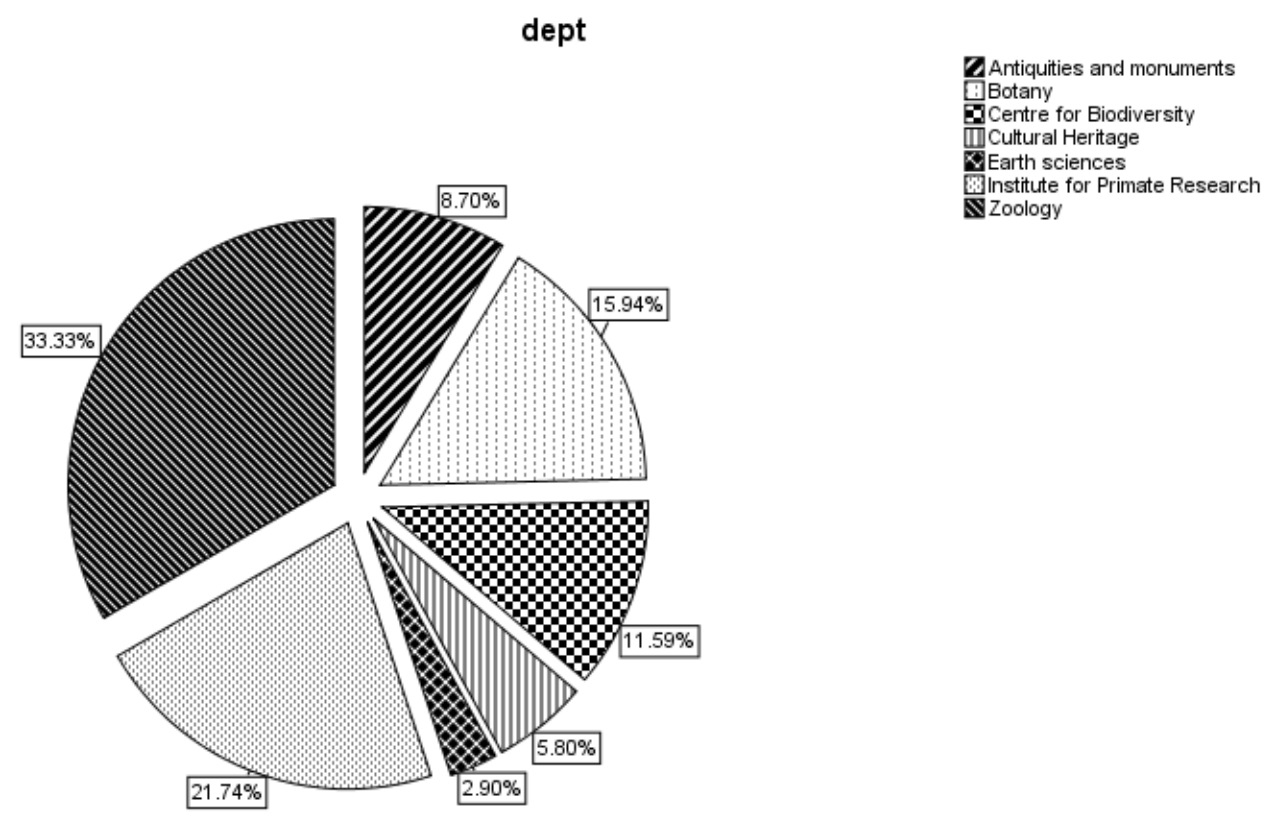

Figure 1: Distribution of respondents by department 
Ojwang' / International Journal of Research in Business and Social Science,

Vol 8 No 1, 2019 ISSN: 2147-4486

\section{Age of respondents}

The study sought to establish the age distribution of Research Scientists at NMK. Data in Table 2 shows the spread of respondents by age group.

Table 2: Distribution of respondents by age

\begin{tabular}{lll}
\hline Age (years) & No. of Research scientists & Percent \\
\hline $26-30$ & 8 & 11.1 \\
$31-35$ & 7 & 9.7 \\
$36-40$ & 17 & 23.6 \\
$41-45$ & 22 & 30.6 \\
$46-50$ & 9 & 12.5 \\
$51-55$ & 6 & 8.3 \\
$56-60$ & 3 & 4.2 \\
Total & 72 & 100.0 \\
\hline
\end{tabular}

Majority of the respondents (30.6\%) are in the age group (41-45 years) while only $4.2 \%$ are above the age of 55. It can be concluded that majority of Research scientists at NMK are in mid-career (31-50 years. 76.4\% fall in this category.

\section{Respondents' gender}

The study sought to find out the composition of Research Scientists at NMK by gender. Figure 2 indicates the composition of respondents by gender.

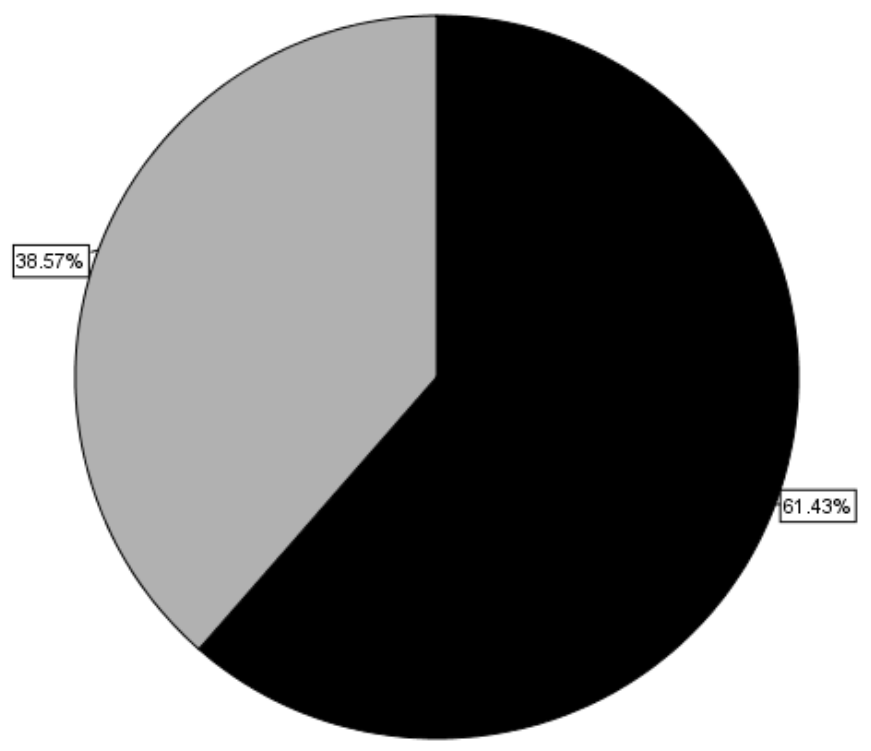

$$
\begin{array}{|c|}
\hline \text { gender } \\
\text { male } \\
\square \text { female } \\
\hline
\end{array}
$$

Figure 2: Distribution of respondents by gender

$61.34 \%$ of respondents were male while $38.57 \%$ were female. The results indicate that the greater proportion of Research scientists working at NMK is male. Scientific research in Kenya has traditionally been seen as a male domain. This could explain the comparatively higher proportion of male Research Scientists at NMK. The lengthy period of academic study (doctorate is seen as a bare minimum for success) coupled with time spent on fieldwork means the question of work-life balance becomes more critical and keeps women at a disadvantage. 


\section{Marital status of respondents}

The study also sought to establish the distribution of Research Scientists at NMK by marital status. Data in Table 3 shows spread of respondents by marital status.

Table 3: Respondents' marital status

\begin{tabular}{llll}
\hline Marital status & & No. of research scientists & Valid Percent \\
\hline Valid & Single & 14 & 19.7 \\
& Married & 55 & 77.5 \\
& Separated & 1 & 1.4 \\
& Widowed & 1 & 1.4 \\
& Total & 71 & 100.0 \\
Missing & System & 1 & \\
Total & & 72 & \\
\hline
\end{tabular}

$77.5 \%$ of the respondents are married while $19.7 \%$ are single. An equal proportion (1.4\%) are separated and widowed. It can therefore be concluded that the vast majority of Research scientists at NMK are married.

\section{Respondents' highest academic qualification}

The study sought to find out the highest academic qualifications of Research Scientists at NMK. Results are presented in Table 4.

Table 4: Respondents' highest level of education

\begin{tabular}{llll}
\hline Highest level of education & No. of Research scientists & Valid Percent \\
\hline Valid & Diploma & 1 & 1.4 \\
& Bachelor's degree & 14 & 20.0 \\
& Master's degree & 33 & 47.1 \\
& PhD & 22 & 31.4 \\
& Total & 70 & 100.0 \\
Missing & System & 2 & \\
Total & & 72 & \\
\hline
\end{tabular}

Majority (47.1\%) are Master's degree holders with a significant proportion (close to a third) holding a PhD. Virtually all respondents $(98.5 \%)$ have at least a first degree. The PhD is seen as a base minimum requirement by research institutions and research funding agencies. Given that NMK is a research institution it is expected that a large number of Research scientists will have PhDs.

\section{Respondents' length of service at the organisation}

Respondents were requested to state how long they had worked with the organisation. Table 5 indicates the spread of respondents based on work experience gained at NMK.

Table 5: Respondents' length of service at NMK

\begin{tabular}{lll}
\hline Length of service at NMK & No. of Research Scientists & Percent \\
\hline $0-5$ & 12 & 16.7 \\
$6-10$ & 10 & 13.9 \\
$11-15$ & 22 & 30.6 \\
$16-20$ & 16 & 22.2 \\
$21-25$ & 8 & 11.1 \\
$26-30$ & 4 & 5.6 \\
Total & 72 & 100.0 \\
\hline
\end{tabular}

Majority of the respondents (30.6\%) have served at NMK for between 11-15 years, $22.2 \%$ have worked for between $16-20$ years while $5.6 \%$ have over 25 years work experience at NMK. In fact $69.4 \%$ have over 10 
years experience. It can be concluded that majority of Research scientists have worked at NMK for a long time. This could be attributed to the amount of time required to attain academic qualifications as well as build networks.

\section{Talent Management practices}

This study intended to determine the influence of Talent Management practices on Research Scientists' Turnover Intent at NMK. Respondents were requested to rate their opinion on a 5 point Likert scale for 40 items representing six components of Talent Management. The results are presented below.

\section{Recruitment and selection}

Respondents were required to indicate on a scale of 1 to 5 , the degree to which they agreed with five statements designed to measure the effectiveness of Recruitment and Selection practices. Higher numbers indicate a stronger belief that the statement is true. Results are outlined in Table 6.

Table 6: Recruitment and selection

\begin{tabular}{|c|c|c|}
\hline & Mean & $\begin{array}{l}\text { Std. } \\
\text { Deviation }\end{array}$ \\
\hline $\begin{array}{l}\text { I was fully informed about the qualifications required to perform the job prior to my } \\
\text { hiring. }\end{array}$ & 4.15 & 0.944 \\
\hline $\begin{array}{l}\text { Wherever possible, vacancies arising are filled by qualified employees working in the } \\
\text { organisation. }\end{array}$ & 3.38 & 1.080 \\
\hline $\begin{array}{l}\text { At NMK there is a formalised induction and orientation program to help new recruits } \\
\text { understand the organisation. }\end{array}$ & 3.15 & 1.195 \\
\hline $\begin{array}{l}\text { NMK recruits employees from diverse backgrounds regardless of tribe, gender, } \\
\text { national origin or religion. }\end{array}$ & 3.69 & 1.158 \\
\hline NMK makes use of its current employees to source for recruits. & 2.99 & 1.028 \\
\hline Average Mean/SD & 3.4722 & 0.75082 \\
\hline
\end{tabular}

With a mean of 4.15 , respondents agreed that they were duly informed about qualifications required prior to their hiring. The corresponding standard deviation of 0.944 shows that although there was variance this was not significant. There was only a modest agreement on the question as to whether vacancies were filled internally (mean score 3.38) and whether NMK recruited employees from diverse backgrounds (mean score of 3.69). Standard deviations of 1.080 and 1.158 respectively for these two items indicate significant variation in responses. As to whether a formal induction program was in place respondents only slightly agreed (mean score 3.15). The SD for this item was 1.195 indicating significant variation in responses. As is evident from the mean score of 2.99 and a SD of 1.028 , majority of respondents were non-committal on the question of whether NMK made use of employee referrals in its recruitment.

From the above analysis, it is evident that NMK provides adequate information to applicants and recruits employees from diverse backgrounds both internally and externally. There is a positive element of formalised induction though not fully satisfactory.

\section{Employee Engagement}

For Employee Engagement, respondents were requested to indicate on a 5 point scale the extent of their agreement with six items designed to gauge the level of engagement. Higher numbers are indicative of a stronger level of agreement. Results are summarised in Table 7.

Table 7: Employee engagement

\begin{tabular}{lll}
\hline & Mean & Std. Deviation \\
\hline Am proud to be working with NMK. & 4.21 & 0.691 \\
Would recommend NMK to family and/or friends as a great place to work. & 3.90 & 0.891 \\
Am committed to improving service quality. & 4.58 & 0.575 \\
Am committed to our department's success. & 4.68 & 0.526 \\
When at work i am completely focused on my job duties. & 4.33 & 0.769 \\
Am willing to take on new tasks as required. & 4.43 & 0.747 \\
Average Mean/SD & 4.3565 & 0.52355 \\
\hline
\end{tabular}


Majority of respondents are proud to be working with NMK (mean score of 4.21), would recommend NMK as a great place to work (mean score of 3.90), are committed to improving service quality (mean score of 4.58), are committed to their department's success (mean score of 4.68), are completely focused on their duties (mean score of 4.33) and are willing to take on new tasks as required (mean score of 4.43). Standard deviation for the 6 items ranges from 0.526 to 0.891 suggesting a high level of consensus among the respondents. These statistics point to very high levels of engagement among Research Scientists at NMK especially in terms of employee commitment to departmental success, service quality improvement, willingness to take on new tasks and focus on job duties.

\section{Performance Management}

Respondents were requested to show on a 5 point scale the extent of their agreement with six items designed to measure Performance Management at NMK. The higher numbers indicate a higher degree of agreement with the statement. Results are summarised on Table 8.

Table 8: Performance Management

\begin{tabular}{lll}
\hline & & Std. \\
& Mean & Deviation \\
\hline Understand how my performance is evaluated. & 3.64 & 1.130 \\
Understand the link between my performance and my pay. & 2.81 & 1.146 \\
Receive regular performance reviews. & 3.26 & 1.126 \\
Supervisor is honest and fair in my performance review and provides constructive & 3.78 & 1.091 \\
feedback. & 3.38 & 1.192 \\
Performance appraisal helps to improve my performance. & 3.13 & 0.948 \\
Performance appraisal clearly indicates any training that i might need. & 3.3310 & 0.78448 \\
Average Mean/SD & & \\
\hline
\end{tabular}

There was a modest level of agreement among respondents on whether they understood how their performance was evaluated (mean score of 3.64) and on whether their supervisor provided honest, fair and constructive feedback (mean score of 3.78). There was only slight agreement on whether respondents received regular performance reviews (mean score of 3.26), whether appraisal helped to improve performance (mean score of 3.38) and whether appraisal indicated training needs (mean score of 3.13). As to whether they understand the link between their performance and pay, majority of respondents were in disagreement (mean score of 2.81). SD for the responses ranged from 0.948 and 1.1192 indicating a considerable amount of variation in the responses. It can be concluded that Research Scientists at NMK understand how their performance is evaluated and that supervisors are honest and fair in performance review. However, they seem to be unsure about the link between pay and performance. Performance appraisal is conducted only fairly regularly and does not always indicate training needs.

\section{Learning and development}

Respondents were requested to indicate on a 5 point scale the degree to which they concurred with 6 statements designed to gauge Learning and Development at NMK. Results are shown in Table 9.

Table 9: Learning and development

\begin{tabular}{lll}
\hline & Mean & Std. \\
& 4.07 & 1.066 \\
\hline I have many opportunities at work to learn new things and grow. & 4.21 & 0.887 \\
Am continuously learning and trying to improve myself. & 2.71 & 0.999 \\
The organisation uses a systematic process for identifying employee development & & \\
needs and implementing solutions. & 3.18 & 1.105 \\
Employees are continually developed through training, education, and opportunities & & \\
for promotion. & 4.19 & 0.850 \\
I have the training needed to succeed in my role. & 3.00 & 1.126 \\
New workers are oriented and are able to come up quickly without undue burden on & & \\
existing staff. & 3.5602 & 0.68422 \\
Average Mean/SD & & \\
\hline
\end{tabular}

Majority of respondents (mean score of 4.07 ) agreed that they had ample opportunities to learn and grow. A $\mathrm{SD}$ of 1.066 for this item suggests considerable variation in responses. Respondents also agreed that they 
were continuously learning and trying to improve themselves (mean score of 4.21) and that they had the training required to succeed in their roles (mean score of 4.19). SD of 0.887 and 0.850 for the two items respectively suggest insignificant variation in the responses. On the other hand, a significant number of respondents disagreed with the statement that a systematic process existed to identify development needs (mean score of 2.71). As to whether employees were continually developed through various interventions, there was only slight agreement with a significant number remaining neutral (mean score of 3.18). The corresponding SD of 1.105 for this item shows that there was significant variation. There was no clear concurrence on the question of orientation of new employees as evidenced by the mean score of 3.00 and corresponding SD of 1.126 .

From these results it can be inferred that ample learning and growth opportunities exists for Research Scientists at NMK and that they are constantly striving to improve themselves. However identification of training needs is not methodical. In addition proper orientation of new staff so that they do not burden existing staff is lacking.

\section{Compensation and rewards}

Respondents were required to indicate on a 5 point scale to what degree they were in agreement with five statements designed to gauge satisfaction with Compensation and Rewards at NMK. Results are summarised in Table 10.

Table 10: Compensation and reward

\begin{tabular}{llc}
\hline & Mean & Std. Deviation \\
\hline Am fairly paid for the work that I do. & 2.64 & 1.142 \\
Am satisfied with my total compensation package offered by NMK. & 2.39 & 1.029 \\
My pay is fair compared to people in similar roles in similar organisations. & 2.15 & 1.002 \\
Am satisfied with health care benefits offered by NMK. & 2.50 & 1.126 \\
Benefits offered by NMK meet my needs. & 2.36 & 1.079 \\
Average Mean/SD & 2.4083 & 0.88457 \\
\hline
\end{tabular}

Mean scores were consistently low across all five items with only one item returning a score above 2.50 . With a mean score of 2.64, respondents disagreed that they were fairly paid for the work they did. They were also dissatisfied with the overall offering (mean score of 2.39). The feeling that their pay measured against that of comparable others was not fair, was particularly strong (mean score of 2.15). They were also dissatisfied with health care benefits offered by NMK (mean score of 2.50) and felt that benefits offered did not meet their needs (mean score of 2.36). SD for the five items ranged from 1.002 to 1.142 suggesting considerable variation in responses even though there was apparent overall dissatisfaction with compensation and rewards. There is a general consensus among the Research scientists at NMK that pay is not fair both in itself and when measured against comparable others. In addition there is overall dissatisfaction with the total compensation package and a feeling that benefits offered do not in the main meet expectations.

\section{Career management}

Respondents were requested to mark on a 5 point scale the degree to which they concurred with 6 items designed to gauge Career Management at NMK. Results are presented in Table 11.

Table 11: Career Management

\begin{tabular}{lll}
\hline & & \\
& Mean & Std. \\
& Deviation \\
\hline There is opportunity for me to advance at NMK. & 3.89 & 1.069 \\
My Supervisor or someone at work has given me proper feedback on how I can & 3.36 & 1.130 \\
advance my career at NMK. & & \\
Am more efficient in my job compared to when I started. & 4.33 & 0.805 \\
There is equal opportunity for advancement at NMK. & 3.14 & 1.104 \\
I find my day-to-day work challenging and interesting. & 3.97 & 0.872 \\
I can achieve my career goals at NMK. & 3.81 & 0.959 \\
Average Mean/SD & 3.7500 & 0.66432 \\
\hline
\end{tabular}

Respondents agreed that opportunities did exist for them to advance (mean score of 3.89). A SD of 1.069 for this item suggests considerable variation in responses. They also agreed that they were more efficient 
compared to when they started (mean score of 4.33), that they found their day-to-day work challenging/interesting (mean score of 3.97) and that they could achieve their career goals at NMK (mean score of 3.81). SD for these three items ranged from 0.805 to 0.959 suggesting a considerable level of consensus among respondents. The items "supervisor feedback" and "equal opportunity for advancement" had the lowest mean scores at 3.36 and 3.14 respectively. The corresponding SD for the two items was 1.130 and 1.104 respectively indicating that there was a considerable amount of variation in responses. It can be concluded that although majority of Research scientists at NMK believe that advancement opportunities exist and that they can achieve their career goals they are less confident about existence of equal opportunity for advancement. It is also worth noting that the scientists find their work challenging and interesting. Finally majority are currently more efficient compared to when they started indicative of a positive element of learning and development.

\section{Employee Turnover Intent}

Employee Turnover Intent was measured using eight items on a 5 point Likert scale. Respondents were requested to circle the number which best indicated their agreement with the statements designed to gauge their Turnover Intent. Results are presented in Table 12 below.

Table 12: Employee Turnover Intent

\begin{tabular}{lll}
\hline & & \\
& Mean & Std. Deviation \\
\hline I think a lot about leaving NMK. & 2.89 & 1.042 \\
Am actively searching for an alternative to NMK. & 2.71 & 1.013 \\
As soon as it is possible i will leave NMK. & 2.74 & 0.993 \\
If i received an attractive offer from another organisation, i would take it. & 3.67 & 0.888 \\
Am planning to work for another organisation within the next 3years. & 2.81 & 0.929 \\
Feel like part of the family at NMK. & 3.83 & 0.787 \\
Really care about the future of NMK. & 4.13 & 0.670 \\
Would be happy to spend the remainder of my career with NMK. & 3.33 & 0.964 \\
\hline
\end{tabular}

As to whether they thought about leaving NMK, the respondents disagreed (mean score of 2.89). They also disagreed that they were searching for alternatives to NMK (mean score of 2.71) and that they would leave the organisation as soon as it were possible (mean score of 2.74). SD for these first three items ranged from 0.993 to 1.042 suggesting a considerable level of variance in the responses. It must be noted that a significant number of respondents were non-committal on these three items which explains why the scores tended towards neutral. The question as to whether respondents would take up an attractive job offer from another organisation returned a significantly high score of 3.67 suggesting that a sizeable number would at least consider such an opportunity. The SD of 0.888 is indicative of consensus on this count. With a mean score of 2.81, respondents disagreed that they were intending to work for another organisation inside the coming three years. The SD of 0.929 for this item shows considerable consensus. Again it must be pointed out that a sizable proportion of respondents remained neutral here. Respondents further agreed that they felt like part of family at NMK (mean score of 3.83) and that they did care about the future of NMK (mean score of 4.13). SD of 0.787 and 0.670 respectively for these two items points to a reasonable degree of consensus. As to whether they would be happy to spend the rest of their career at NMK, respondents returned a mean score of 3.33 which would suggest that majority were non-committal. A SD of 0.964 indicates there was no significant variation in responses on this count. From these results it can be deduced that the intention to leave among Research scientists at NMK is relatively low. It is instructive to note however that over half would consider taking up a more attractive offer were it to present itself.

\section{Influence of Talent Management practices on Employee Turnover Intent}

The main objective of this study was to establish the influence of Talent Management practices on employee turnover intent. To achieve this, Multiple Linear Regression (MLR) analysis was done using the SPSS software. Results of this analysis are given below.

Table 13 shows the result of testing the fit of the model. The multiple correlation $(R)$ is .421 with a corresponding $R$ square value of .178 , suggesting that $17.8 \%$ of the variance in employee turnover intent at NMK is explained by the set of predictors. 
Table 13: Overall model fit

Model Summary

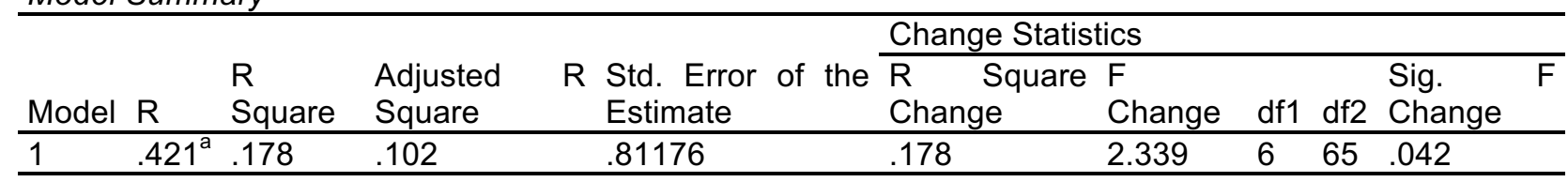

a. Predictors: (Constant), Career, Recruitment, Compensation, Engagement, Performance, Learning

The ANOVA table in Table 14 provides a test of the statistical significance of the regression model. The $p$ value of 0.042 indicates that regression was significant in predicting how Talent Management practices influence employee turnover intent at NMK. If a null hypothesis were to be tested in this study it would have been rejected and the alternative picked given that $p$ value $<0.05$.

Table 14: ANOVA

ANOVA $^{a}$

\begin{tabular}{lllllll}
\hline Model & & Sum & of & & & \\
\hline 1 & Regression & Squares & Df & Mean Square & F & Sig. \\
\hline & Residual & 42.832 & 6 & 1.541 & 2.339 & $.042^{\mathrm{b}}$ \\
& Total & 52.080 & 65 & .659 & & \\
\hline
\end{tabular}

a. Dependent Variable: Turnover

b. Predictors: (Constant), Career, Recruitment, Compensation, Engagement, Performance, Learning

Table 15 presents the coefficients table for the variables in the regression model. Only Employee engagement with a value of $0.039<0.05$ has a significant relationship with employee turnover intent. This can also be seen in the relatively higher values of standardised and unstandardised regression coefficients for this variable. When controlling for other models in the regression model, an increase of one unit in employee engagement is expected to be associated with a .398 rise in employee turnover intent.

Table 15: Coefficients

Coefficients $^{a}$

\begin{tabular}{|c|c|c|c|c|c|c|c|}
\hline \multirow[b]{2}{*}{ Model } & \multicolumn{2}{|c|}{$\begin{array}{l}\text { Unstandardised } \\
\text { Coefficients }\end{array}$} & \multirow{2}{*}{$\begin{array}{l}\text { Standardized } \\
\text { Coefficients } \\
\text { Beta }\end{array}$} & \multirow[b]{2}{*}{ T } & \multirow[b]{2}{*}{ Sig. } & \multicolumn{2}{|l|}{$\begin{array}{l}\text { Collinearity } \\
\text { Statistics }\end{array}$} \\
\hline & $\mathrm{B}$ & Std. Error & & & & Tolerance & VIF \\
\hline 1 (Constant) & .994 & .826 & & 1.204 & .233 & & \\
\hline Recruitment & -.042 & 119 & -.043 & -.348 & .729 & .826 & 1.211 \\
\hline Engagement & .398 & 189 & .267 & 2.103 & .039 & .783 & 1.277 \\
\hline Performance & 102 & 138 & .107 & .738 & .463 & .597 & 1.676 \\
\hline Learning & -.010 & .169 & -.009 & -.061 & .952 & .539 & 1.855 \\
\hline Compensation & .214 & .114 & .253 & 1.868 & .066 & .688 & 1.453 \\
\hline Career & -.034 & .149 & -.032 & -.225 & .823 & .608 & 1.645 \\
\hline
\end{tabular}

a. Dependent Variable: Turnover

Fitting values into the regression equation:

$y=\beta_{0}+\beta_{1} x_{1}+\beta_{2} x_{2}+\beta_{3} x_{3}+\beta_{4} x_{4}+\beta_{5} x_{5}+\beta_{6} x_{6}+\varepsilon$

$\mathrm{y}=.994-0.042 \mathrm{x}_{1}+0.398 \mathrm{x}_{2}+0.102 \mathrm{x}_{3}-0.010 \mathrm{x}_{4}+0.214 \mathrm{x}_{5}-0.034 \mathrm{x}_{6}+0.826$

Where:

$\mathrm{y}$ is employee turnover intent

$\beta_{0}$ is the constant

Peer-reviewedAcademicJournalpublishedby SSBFNET withrespecttocopyrightholders. 
$\beta_{n}(n=1 \ldots . .6)$ is the coefficient of determinant

$\mathrm{x}_{1}$ is Recruitment and Selection

$\mathrm{x}_{2}$ is Employee Engagement

$\mathrm{x}_{3}$ is Performance Management

$\mathrm{x}_{4}$ is Learning and Development

$\mathrm{x}_{5}$ is Compensation and Rewards

$\mathrm{x}_{6}$ is Career Management

$\varepsilon$ is the error term.

According to the regression model established, when controlling for other predictors, an increase of one unit of Employee Engagement is expected to be associated with a 0.398 unit gain in Employee Turnover Intent. Similarly, when controlling for other predictors in the model, an increase of one unit of Compensation and Rewards is expected to be associated with a 0.214 unit gain in Employee Turnover Intent.

\section{Discussion of Key Findings}

This study set out to determine the influence of Talent Management practices on turnover intent among Research scientists at NMK.

With regards to recruitment and selection, the study established that majority of respondents were fully aware of qualifications before joining the organisation. A modest majority concurred that a formal induction program for new recruits existed while less than a third agreed that NMK made use of employee referrals in recruitment. Incorporating all important matters into a formalised induction programme guarantees that new starters are brought up to speed faster and that they are less likely to depart early (Torrington et al, 2008). Formalised introduction schemes supply candidates with a more realistic view of the organisation and candidates who join an organisation via this route are likely to be more suitable and stay longer (Price, 2015).

The study found engagement levels among research scientists at NMK to be high with employee engagement registering the highest mean score of all the variables under study. Indeed, only employee engagement turned out to be a significant predictor of employee turnover intent at NMK. Armstrong (2007) warns though that engagement among knowledge workers and especially researchers can be problematic. He states that they may be more interested in research facilities and an opportunity to create a name rather than commitment to the organisation. It is worth stating here that some of the respondents in this study cited the environment at NMK as very conducive for conducting research. It was also revealed from the study that performance reviews are conducted regularly and that employees understand how their performance is evaluated. In addition, it was established that supervisors are not only fair and honest in assessing, they also provide constructive feedback. However, it was apparent from the study that appraisal did not clearly highlight training needs and that the link between performance and pay was not well understood. What gets rewarded gets done. A major use of reward systems is to spell out the objectives of the organisation. Employees want to know what they are being rewarded on so they can concentrate their efforts on that. It is not just enough to measure what counts and ensure that it is done. Lack of performance recognition will eventually lead to a decline in productivity along with retention rates. Although an overwhelming majority of respondents agreed that opportunities to learn and grow were available, the study found out that only a comparatively measly proportion felt that the organisation used a systematic process for training needs assessment. Similarly only a comparatively modest proportion agreed that new employees were properly oriented. According to Harris and Brannick (1999), whereas programs and seminars directed at employees in an unsystematic manner might improve skills and knowledge they have little impact on operational performance because the training has no clear connection to the company core culture.

Turning to compensation and rewards, respondents were found to be clearly dissatisfied. They felt that there pay was not only unfair in general terms but also that it not fair when measured against industry peers. According to Caldwell (2000), employees tend to view pay as important but not necessarily the most important thing. In any case trying to use money to keep an already disengaged employee only leads to a well paid disconnected employee with an opportunity to disconnect other great employees (Harris and Brannick, 1999). A great deal of importance is placed on less tangible things such as recognition and advancement opportunities. Majority of respondents in this study were what Armstrong calls "mid career employees" (aged 31-50) for whom ability to manage career and satisfaction are important. The fact that close to a third of the respondents are PhD holders could be pointer to this. Scientists with a doctorate are more likely to enjoy access to networking with research funding agencies and tenured scientists both locally 
and globally. On career management, the study revealed that just over a third of respondents felt that there was equal opportunity for advancement, even though the vast majority believed that opportunities did exist and that they could achieve their goals at NMK. According to Price (2015), an organisation's commitment to equality of opportunity leads to an environment that encourages employees to stay.

With regards to employee turnover intent the study indicated a generally low intention among Research scientists to leave NMK. Interestingly however, majority (more than half) conceded that they would take up an attractive offer from another organisation if it arose. As if in contradiction only a comparatively lower proportion of less than a fifth are actively searching for alternatives to NMK. This would suggest that they are on the whole satisfied with NMK as a place to work. This could be supported by the findings that majority do feel as part of family at NMK, that they care about the organisation's future and finally that they would be happy to spend the remainder of their career at NMK

\section{Conclusions}

This study has established that employee engagement is a significant predictor of Turnover Intent. Engagement is the degree to which employees pledge their discretional effort to the organisation. Employees not feeling commitment to their work are unlikely to remain in the employment of the organisation.

NMK should develop effective retention strategies that will make sure that Research Scientists remain engaged and committed to the organisation. A key component of this strategy should be an integrated total rewards scheme with non-financial factor as one of the components. Given that majority of the Research Scientists are mid career employees, development and career opportunities should be key. Majority of the scientists are married and presumably have families to take care of. Women form a significant proportion of the scientists. Work life balance should therefore form a natural component of reward scheme. Discretionary financial rewards (bonuses) are used to drive organisational values (strict adherence to professional ethics) and outcomes (research funding). So that they retain the incentive value and help build strong employee-toorganisation connections, it is recommended that their award reflect the extent to which the objectives have been attained.

It is recommended that formal induction programs be put in place. Such a forum could be used to communicate important cultural messages regarding what NMK expects and what employees can in turn expect. This constitutes an important step in the establishment of a psychological contract. Research being a collaborative undertaking, such forums could enable young scientists especially to initiate contacts with more established scientists forming the basis of possible mentorship.

A systematic learning and development scheme should be put in place with individualised plans for each scientist as the cornerstone. A key plank for the individual learning and development programs should be mentorship. High levels of education and a wealth of experience in research means that the potential for successful mentorship is high. A systematic approach will ensure correct diagnosis and that training interventions are not for example used in attempting to cure deficiencies caused by lack of motivation or environmental problems. It is also recommended that one-on-one discussions with line managers rather than end term sessions be incorporated into the performance management program. This would ensure that corrective action is taken in good time and any opportunities arising in the interim are exploited.

The study was conducted at the tail end of the year during which time a significant number of employees were away on annual leave. This led to a lower response rate than would otherwise have been the case.

The study focused on the influence of Talent Management practices on Turnover Intent among Research scientists at National Museums of Kenya in Nairobi. Future studies should be expanded to include other cadres of employees such as Lab Technologists who work closely with the Research Scientists, are heavily involved in research work and most importantly have a path to become Research Scientists themselves. A similar study should be extended to Research Scientists in other research institutions - both local and international - especially those that work in close collaboration with NMK. These include Kenya Forest Service (KFS), Kenya Wildlife Service (KWS), Kenya Medical Research Institute (KEMRI) and Nature Kenya.

\section{Acknowledgements}

I am grateful to my supervisor, Dr. Florence Muindi for her guidance and insights shared at every stage of this study. My heartfelt appreciation goes to staff of National Museums of Kenya for their unqualified support which rendered completion of this study possible. 


\section{References}

Akhtar, C. S., Aamir, A., Khurshid, M. A., Abro, M. M. Q., \& Hussain, J. (2015). Total rewards and retention: Case study of higher education institutions in Pakistan. Procedia - Social and Behavioral Sciences, 210, 251-259. doi:10.1016/j.sbspro.2015.11.365

Akridge, J. (2016). Results from The 2015 Performance Management in Agribusiness Survey(pp. 3-4, Rep.). Centre for Food and Agricultural Business, Purdue University.

Armstrong, M. (2007). A handbook of human resource management practice. London: Kogan Page.

Ashton, C., \& Morton, L. (2005). Managing talent for competitive advantage: Taking a systemic approach to talent management. Strategic HR Review,4(5), 28-31. doi:10.1108/14754390580000819

Baron, A., \& Armstrong, M. (2007). Human capital management: achieving added value through people. London: Kogan Page Ltd.

Berger, L. A., \& Berger, D. R. (2004). The talent management handbook: creating organizational excellence by identifying, developing, and promoting your best people. New York: McGraw-Hill

Bluen, S. D. (2013). Talent management in emerging markets. Randburg: Knowres.

Branham, L. F. (2005). The 7 hidden reasons employees leave: How to recognize the subtle signs and act before its too late. New York: AMACOM.

Cascio, W. F. (2014). Leveraging employer branding, performance management and human resource development to enhance employee retention. Human Resource Development International,17(2), 121-128. doi:10.1080/13678868.2014.886443

Cropanzano, R. (2005). Social Exchange Theory: An Interdisciplinary Review. Journal of Management, 31(6), 874-900. doi:10.1177/0149206305279602

Davis, P. J. (2015). Implementing an employee career-development strategy. Human Resource Management International Digest,23(4), 28-32. doi:10.1108/hrmid-05-2015-0066

Dessler, G. (2013). Human resource management: Gary Dessler. Pearson Education Limited

Emerson, R. M. (1976). Social Exchange Theory. Annual Review of Sociology, 2(1), 335-362. doi:10.1146/annurev.so.02.080176.002003

Fields, M. R. (2001). Indispensable employees: how to hire them, how to keep them. Franklin Lakes, NJ: Career Press.

Firth, L., Mellor, D. J., Moore, K. A., \& Loquet, C. (2004). How can managers reduce employee intention to quit? Journal of Managerial Psychology, 19(2), 170-187. doi:10.1108/02683940410526127

Foot, M., \& Hook, C. (2005). Introducing human resource management. Essex, England: Financial Times Prentice Hall.

Gómez-Mejía, L. R., Balkin, D. B., \& Cardy, R. L. (2010). Managing human resources: global edition. Boston: Pearson Education.

Graham, H. T., \& Bennett, R. (1998). Human resources management. London: Pitman.

Haider, M., Rasli, A., Akhtar, C. S., Yusoff, R. B., Malik, O. M., Aamir, A., . . Tariq, F. (n.d.). The Impact of Human Resource Practices on Employee Retention in the Telecom Sector. Retrieved from http://www.econjournals.com/index.php/ijefi/article/view/1344

Harris, J., \& Brannick, J. (1999). Finding \& keeping great employees. New York: AMACOM. 
Hayes, D. and Ninemeier, J. (2001). 50 One-minute tips for recruiting employees. Menlo Park, CA: Crisp Publications.

Heathfield, S. M. (n.d.). Why Talent Management Is an Important Business Strategy. Retrieved from https://www.thebalance.com/what-is-talent-management-really-1919221

Herholdt, J. (2012). Optimising talent in organisations: articles from Human Capital Review. Randburg, Republic of South Africa: Knowres Publishing.

Holland, P., Sheehan, C. and De Cieri, H. (2007). Attracting and retaining talent: exploring human resources development trends in Australia. Human Resource Development International, 10(3), pp.247-262.

Hughes, J. C., \& Rog, E. (2008). Talent management. International Journal of Contemporary Hospitality Management,20(7), 743-757. doi:10.1108/09596110810899086

Hlavna, D. P. (1992). Economic Development, Human Capital Theory and the Community College. Community College Review,19(4), 47-51. doi:10.1177/009155219201900407

Isfahani, A. C., \& Boustani, H. (2014). Effects of Talent Management on Employees Retention: The Mediate Effect of Organizational Trust. International Journal of Academic Research in Economics and Management Sciences,3(5). doi:10.6007/ijarems/v3-i5/1196

Johnson, J., \& Fahsholtz, W. (2010). Strategies for Employee Retention: A Ranch Manager's Perspective. Rangelands,32(4), 17-20. doi:10.2111/rangelands-d-10-00033.1

Kataike, S. (2013). Relationship Between Talent Management and Employee Retention in Commercial Banks in Kenya. (Unpublished Masters thesis). University of Nairobi, Nairobi, Kenya

Kibui, A. (2015). Effect of Talent Management on Employees Retention in Kenya's State Corporations. (Unpublished doctoral dissertation). JKUAT, Kenya.

Martin, A. (2015). Talent Management: Preparing a "Ready" agile workforce. International Journal of Pediatrics and Adolescent Medicine,2(3-4), 112-116. doi:10.1016/j.ijpam.2015.10.002

Mccracken, M., Currie, D., \& Harrison, J. (2015). Understanding graduate recruitment, development and retention for the enhancement of talent management: sharpening 'the edge' of graduate talent. The International Journal of Human Resource Management,27(22), 2727-2752. doi:10.1080/09585192.2015.1102159

Morgan, J. (2014). The future of work: attract new talent, build better leaders, and create a competitive organization. Hoboken, $\mathrm{NJ}$ : Wiley.

Mugenda, O. M., \& Mugenda, A. G. (1999). Research methods: Quantitative and qualitative approaches. Nariobi, Kenya: African Centre for Technology Studies.

Narayanan, A. (2016, August 25). Talent Management and Employee Retention: Implications of Job Embeddedness - A Research Agenda. Retrieved from http://ssrn.com/abstract=2829273

Noe, R. A. (2010). Human resource management: gaining a competitive advantage. Boston: McGraw-Hill Irwin.

Oladapo, V. (2014). The impact of Talent Management on Retention. Journal of Business Studies Quarterly, 5(3), 20-36.

OMeara, B., \& Petzall, S. B. (2013). The handbook of strategic recruitment and selection: a systems approach. Bingley: Emerald.

Price, A. (2015). Human resource management in a business context. Mason: South-Western Cengage Learning.

Rankin, N. (2003). Best practice in HR. London: Tolley. 
Robinson, I. (2006). Human resource management in organisations (1st ed.). London: Chartered Institute of Personnel and Development.

Santhanam, N., T.j., K., Dyaram, L., \& Ziegler, H. (2017). Impact of human resource management practices on employee turnover intentions. Journal of Indian Business Research, 9(3), 212-228. doi:10.1108/jibr-10-2016-0116

Smith, A., Oczkowski, E., \& Smith, C. S. (2011). To have and to hold: modelling the drivers of employee turnover and skill retention in Australian organisations. The International Journal of Human Resource Management, 22(2), 395-416. doi:10.1080/09585192.2011.540162

Stewart-Burton, J. (2016, July 1). Talent Management Matters. Agri Marketing.

Talent strategy in an unpredictable world. (n.d.). Retrieved from https://www.pwc.com/ee/et/publications/pub/people-and-purpose.pdf

Thite, M. (2010). All that Glitters is not Gold: Employee Retention in Offshored Indian Information Technology Enabled Services. Journal of Organizational Computing and Electronic Commerce,20(1), 7-22. doi:10.1080/10919390903482390

Torrington, D., Hall, L., \& Taylor, S. (2008). Human resource management. Harlow: Pearson Education.

Torrington, D. (2011). Human resource management. Harlow, England: Financial Times/Prentice Hall.

Yonga, P. O., Muchiri, H. M., \& Onyino, A. W. (2012). Perceptions of medical brain drain among young doctors in Kenya: a cross-sectional survey. The Lancet,380. doi:10.1016/s0140-6736(13)60308-6 